Artikel Penelitian

\title{
Pengaruh Minimisasi Energi MMFF94 dengan MarvinSketch dan Open Babel PyRx pada Penambatan Molekular Turunan Oksindola Tersubstitusi
}

\author{
Atika Umi Hanif1', Prima Agusti Lukis², Arif Fadlan ${ }^{1 *}$ \\ 1Departemen Kimia, Fakultas Sains dan Analitika Data, Institut Teknologi Sepuluh Nopember, Surabaya, Indonesia, 60111 \\ 2Diploma III Teknik Gigi, Fakultas Kedokteran Gigi, Institut IImu Kesehatan Bhakti Wiyata, Kediri, Indonesia, 64114
}

\section{INFO ARTIKEL}

\section{Riwayat Artikel}

Diterima 1 Desember 2020

Direvisi 28 Desember 2020

Tersedia online 30 Januari 2021

*Email penulis korespondensi:
afadlan@chem.its.ac.id

\section{ABSTRAK}

In silico technique is widely used for drug discovery because it can predict the conformation of ligands in protein macromolecules and it can calculate the binding affinity. The energy minimization is carried out to make the ligand more stable near the initial state during molecular docking process. The Merck Molecular Force Field (MMFF94) is one type of energy minimization process often used in organic compounds. The molecular docking of substituted oxindole derivatives on indoleamine macromolecules 2,3-dioxygenase (IDO-1, PDB: 2D0T) by MMFF94 minimization operated by MarvinSketch and Open Babel in PyRx showed different results. The binding affinity energy obtained was also quite different, but the ligands have the same conformation and bind the same residue with slightly different bond distances.

Keywords: Molecular docking, energy minimization, substituted oxindole, Merck Molecular Force Field 94

Teknik in silico banyak digunakan untuk penemuan senyawa obat karena dapat memprediksi konformasi suatu ligan dalam makromolekul protein dan mampu menghitung nilai afinitas ikatan. Proses minimisasi energi dilakukan untuk menjadikan ligan lebih stabil mendekati keadaan awal selama penambatan molekular berlangsung. Merck Molecular Force Field (MMFF94) adalah salah satu jenis persamaan minimisasi energi yang sering digunakan pada senyawa organik. Hasil pengujian pengaruh minimisasi energi dengan MMFF94 menggunakan program MarvinSketch dan Open Babel dalam PyRx pada turunan oksindola tersubstitusi alkil terhadap makromolekul 2,3-dioxygenase indoleamine (IDO-1, PDB: 2D0T) menunjukkan hasil dengan nilai yang berbeda. Energi afinitas ikatan yang didapatkan juga cukup berbeda, namun ligan memiliki konformasi yang sama dan mengikat residu yang sama dengan jarak ikatan yang sedikit berbeda.

Kata kunci: Penambatan molekular, minimisasi energi, oksindola tersubstitusi, Merck Molecular Force Field 94

\section{Pendahuluan}

Indoleamin 2,3-dioksigenase (IDO) dalam bentuk IDO1, IDO2, dan triptopan dioksigenase (TDO) adalah sekelompok enzim yang secara umum berkaitan erat dengan sistem kekebalan tubuh atau imun [1]. Peningkatan sistem imun dan syaraf (imunoaktif dan neuroaktif) diketahui sangat bergantung pada metabolisme asam amino esensial triptofan melalui jalur kinurenina [2]. Pemecahan triptofan menjadi $\mathrm{N}$-formilkinurenina, 3-hidroksikinurenina, dan asam 3-hidroksiantranilik dapat menurunkan dan menekan sistem imun melalui efek imunosupresif dan menyebabkan terjadinya tumor akibat respon 
imun yang terhambat [3]. IDO1 dilaporkan berperan dalam katabolisme triptofan ini dan diekspresikan secara terus menerus pada berbagai jenis tumor. Berdasarkan hal ini, penemuan agen-agen antikanker dengan target ID01 terus dilakukan untuk meningkatkan pengobatan kanker melalui imunoterapi [2].

Penelitian dalam rangka pencarian agen-agen antikanker dengan memanfaatkan ID01 sebagai target terus dilakukan. Oksindola dan turunannya diketahui dapat berfungsi sebagai agen antikanker karena menghambat kinerja reseptor enzim tirosinase [4]. Pengembangan turunan oksindola terklorinasi dan termetilasi sebagai agen antikanker juga telah dilaporkan oleh Pantouris dkk pada tahun 2016 [5]. Hasil penelitian menunjukkan bahwa klorinasi menghasilkan produk dengan potensi penghambatan yang menjanjikan dan tinggi [6].

Penambatan molekular merupakan teknik simulasi komputasi in silico yang banyak digunakan dalam penelitian obatobatan termasuk pengembangan agen-agen antikanker. Teknik ini dapat memerkirakan konformasi suatu protein dengan molekul atau ligan [7]. Penambatan molekular diawali dengan preparasi dan optimasi molekul dan protein untuk mendapatkan hasil yang baik. Langkah awal ini penting karena penambatan melibatkan pergerakan atom/molekul secara fisik dalam waktu yang dinamik dengan tuntutan kecepatan simulasi pada ketepatan tinggi. Optimasi dapat dilakukan melalui minimisasi energi yang melibatkan kalkulasi mekanika molekul [8].

Minimalisasi energi dapat mempermudah dan menyetabilkan susunan ikatan selama penambatan molekul, penambahan hidrogen, dan konversi struktur dua dimensi menjadi tiga dimensi [9]. Minimisasi energi dengan medan gaya (force field) seperti medan gaya mekanika molekular (molecular-mechanics force fields, MMFF94) juga diketahui dapat digunakan untuk menghitung energi potensial dan parameter lainnya seperti regangan ikatan, sudut lekukan, panjang lekukan, gaya torsi, lekukan out-of-plane, interaksi van der Waals, dan elektrostatik [8]. Akibatnya, optimasi melalui minimisasi energi yang dilakukan dengan baik dan tepat dapat meningkatkan ketepatan dan performa hasil penambatan molekular. Hasil penambatan molekular selanjutnya dilaporkan dalam afinitas ikatan (binding affinity) dan interaksi molekul. Afinitas ikatan mempengaruhi aktivitas intermolekular senyawa dan berimbas pada kekuatan ikatan [10]. Penelitian ini mempelajari pengaruh minimisasi energi terhadap turunan oksindola (Z)-5,7-dikloro-1-metil-3-(2-oksopropilidena)indolin-2ona (1) dan 1-metil-L-triptopan (L-1-MT) (senyawa umum inhibitor ID01) (Gambar 1) yang ditambatkan pada sisi aktif reseptor ID01. Hasil dievaluasi berdasarkan afinitas ikatan dan interaksi yang terjadi antara senyawa 1 dan L-1MT dengan ID01.

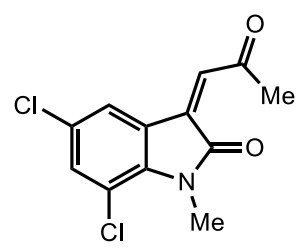<smiles>N[C@H](CC1C(=O)N([N+](=O)[O-])c2ccccc21)C(=O)O</smiles>

L-1MT

Gambar 1. Struktur senyawa 1 dan L-1MT

\section{Bahan dan Metode}

\subsection{Bahan}

Penelitian ini dilakukan dengan laptop ASUS sistem operasi Windows 10 64-bit prosesor Intel $\left(\right.$ Core $^{\mathrm{TM}}$ i7- 4720HQ RAM 4 GB NVIDIA GeForce 940M, MarvinSketch versi 20.13 (ChemAxon, Ltd, https://chemaxon.com), PyRx (Autodock Vina) (https://pyrx.sourceforge.io/), dan PyMOL versi 2.3.4 (Schrodinger,LLC, https://pymol.org). Penambatan molekular senyawa 1 dan ligan L-1-MT dilakukan terhadap makromolekul ID01 yang diunduh dari database protein dari wwPDB (Worldwide Protein Data Bank) dengan identitas atau PDB ID: 2D0T. Senyawa 1 dan L-1MT disiapkan melalui pembuatan struktur dua dimensi (2D) yang dilanjutkan dengan pengaturan pH 7,4 dan konversi menjadi bentuk tiga dimensi (3D) menggunakan MarvinSketch [11, 12]. Optimasi selanjutnya dilakukan melalui minimisasi energi dengan MarvinSketch (a) dan Open Babel PyRx (b), dan tanpa minimisasi energi (c). Senyawa ko-kristal PIM dalam ID01 dipreparasi dan dioptimasi dengan prosedur yang sama. Makromolekul 2D0T dipreparasi dengan penghapusan molekul air, penghapusan ligan kokristal PIM, penghapusan rantai $B$, dan penambahan hidrogen polar menggunakan PyMOL.

\subsection{Penambatan Molekuler}

Penambatan molekular menggunakan AutoDock Vina diawali dengan penambatan ulang ko-kristal PIM terhadap makromolekul 2D0T untuk validasi prosedur penambatan. Penambatan dilakukan pada grid berukuran $12 \AA \times 12 \AA \times 12$ $\AA$ dengan sumbu $X, Y$, dan $Z$ masing-masing sebesar $59 \AA, 53 \AA, 18 \AA$, dan exhaustiveness default sebesar 8 . Nilai Root 
Mean Square Deviation (RMSD) hasil penambatan ulang dapat diterima apabila <2 A [13]. Penambatan silang 1 dan L-1MT dilakukan sebagaimana prosedur penambatan ulang menggunakan senyawa hasil preparasi dan optimasi melalui minimisasi energi dan tanpa minimisasi energi. Visualisasi menggunakan PyMOL dilakukan untuk mengetahui mode dan tipe interaksi yang terjadi antara senyawa dan makromolekul 2D0T.

\section{Hasil dan Pembahasan}

\subsection{Preparasi Ligan dan Makromolekul 2D0T}

Minimisasi energi 1 dan L-1MT menggunakan MarvinSketch (a) dan Open Babel PyRx (b), dan tanpa minimisasi energi (c) menghasilkan konformasi struktur 3D dengan energi minimisasi sebagaimana dapat dilihat pada Tabel 1. Minimisasi energi dengan Open Babel PyRx menghasilkan ligan 1b dan L-1MTb dengan nilai energi minimisasi (EM) yang lebih rendah. Minimisasi energi yang menggambarkan kestabilan konformasi struktur molekul berdasarkan nilai EM [9] menginformasikan bahwa algoritma conjugate gradient Open Babel dalam PyRx menghasilkan regangan ikatan (bondstretching), sudut lekukan (bending), panjang lekukan, gaya torsinal (torsion force), lekukan out-of-plane, interaksi van der Waals, dan elektrostatik yang lebih baik untuk kestabilan senyawa 1 dan L-1MT [14, 15]. Algoritma conjugate gradient Open Babel diketahui merupakan algoritma umum yang digunakan untuk menyelesaikan sistem persamaan linier berdasarkan penemuan titik minimum dari suatu fungsi kuadrat [16]. Sementara itu, ligan 1a dan L-1MTa yang dihasilkan dari minimisasi energi menggunakan MarvinSketch memberikan hasil yang berbeda dengan nilai EM yang lebih tinggi. Hasil ini menunjukkan bahwa algoritma divide and conquer pada MarvinSketch tidak cukup menghasilkan ligan 1a dan L1MTa dengan kestabilan, energi potensial, dan parameter lain yang lebih rendah dari ligan $1 \mathrm{~b}$ dan L-1MTb yang diperoleh dengan algoritma conjugate gradient Open Babel.

Tabel 1. Nilai Energi Minimisasi (EM) Ligan 1 dan L-1MT

\begin{tabular}{cccc}
\hline Ligan & EM (kkal/mol) & Ligan & EM (kkal/mol) \\
\hline 1a & 28,14 & L-1MTa & 74,28 \\
1b & 21,74 & L-1MTb & 54,05 \\
1c & 88,30 & L-1MTc & 56,80 \\
\hline
\end{tabular}

Makromolekul IDO-1 (PDB ID: 2D0T) mengandung dua rantai identik A dan B dimana setiap rantai memiliki sekuens dengan panjang $406 \AA$ [17]. Penghapusan molekul air dalam makromolekul 2D0T dilakukan untuk menghindari gangguan interaksi selama proses penambatan berlangsung, sedangkan penghapusan ko-kristal PIM dilakukan untuk mendapatkan situs penambatan. Rantai B selanjutnya dihapus dan proses penambatan dilakukan dengan rantai $A$ yang sebelumnya telah ditambah dengan hidrogen polar untuk mengantisipasi interaksi yang terjadi antara senyawa dan makromolekul 2D0T.

\subsection{Penambatan Molekular}

Penambatan ulang ko-kristal PIM pada makromolekul 2D0T terlebih dahulu dilakukan untuk validasi prosedur penambatan. Penambatan ulang dilakukan pada situs ikat ko-kristal PIM pada sumbu X $59 \AA$, sumbu Y $53 \AA$, dan sumbu Z $18 \AA$ dengan grid berukuran $12 \AA \times 12 \AA \times 12 \AA$. Penambatan kembali ko-kristal PIM dengan minimisasi energi MarvinSketch pada situs tambatnya dalam makromolekul 2D0T berhasil dilakukan dan memberikan nilai RMSD sebesar $0,085 \AA$ (Gambar 2). Analisis lebih lanjut menunjukkan bahwa terjadi interaksi ikatan polar antara atom nitrogen cincin pirola pada ko-kristal PIM dengan Heme dalam jarak 2,13 $\mathrm{A}$ dan 3,02 A. Interaksi serupa terjadi melalui ikatan koordinasi. Interaksi phi-phi stacking juga terjadi antara cincin benzena dengan residu TYR126 dan antara cincin pirola dengan ligan Heme $[6,18]$. Ligan ko-kristal PIM hasil penambatan ulang menunjukkan pola interaksi yang sama dengan jarak yang sedikit berbeda (2,64 dan 2,90 А). Parameter RMSD dan interaksi yang terjadi mengindikasikan penambatan ulang dapat diterima dan prosedur penambatan valid sehingga dapat digunakan pada penambatan molekular berikutnya [19]. Penambatan silang senyawa 1 dan L-1MT dilakukan secara selektif sebagaimana prosedur penambatan ulang ko-kristal PIM. Senyawa 1 dan L-1MT ditambatkan pada situs ikat ko-kristal PIM dengan sumbu dan ukuran grid yang sama.

Evaluasi kemudian dilakukan terhadap afinitas ikatan (binding affinity) yang menggambarkan aktivitas intermolekular dan kekuatan ikatan antara protein dan senyawa. Semakin kecil afinitas ikatan maka semakin kuat ikatan protein dan senyawa [8]. Tabel 2 memperlihatkan nilai afinitas ikatan ligan 1a dan L-1MTa masing-masing sebesar -0,3 dan -2,2 $\mathrm{kkal} / \mathrm{mol}$ pada pose terbaik (pose 1) dan nilai ini lebih rendah dari pada yang lain. Hasil ini mengisyaratkan bahwa minimisasi energi berpengaruh terhadap proses penambatan. Kajian lebih lanjut menunjukkan data EM sebagaimana dapat dilihat pada Tabel 1 tidak memiliki hubungan linear dengan nilai afinitas ikatan (Tabel 2).

Minimisasi energi menggunakan algoritma conjugate gradient Open Babel menghasilkan ligan $1 \mathrm{~b}$ dan L-1MTb dengan nilai EM yang lebih rendah dari pada nilai EM untuk ligan 1a dan L-1MTa hasil minimisasi dengan algoritma divide and conquer MarvinSketch. Tetapi, ligan 1a dan L-1MTa dengan nilai EM yang lebih tinggi selanjutnya menghasilkan nilai 
afinitas ikatan yang lebih rendah dari ligan $1 \mathrm{~b}$ dan L-1MTb (Tabel 2). Secara umum, temuan ini dapat dikaitkan dengan penggunaan algoritma yang berbeda antara MarvinSketch dan Open Babel [16, 20]. Algoritma conjugate gradient Open Babel dapat menghasilkan konformasi struktur dengan kestabilan dan energi potensial yang lebih rendah (ligan $\mathbf{1 b}$ dan $\mathbf{L}$ 1MTb), tetapi struktur ini dimungkinkan cukup kaku dan tidak fleksibel dalam protein selama proses penambatan berlangsung. Sebaliknya, meskipun algoritma divide and conquer MarvinSketch menghasilkan struktur dengan EM lebih tinggi (ligan 1a dan L-1MTa) tetapi struktur ini fleksibel dalam protein selama penambatan. Fleksibilitas struktur ligan dalam protein selama proses penambatan berlangsung memberikan nilai afinitas ikatan yang berbeda untuk setiap ligan dengan protein [21]. Fakta ini juga dapat dikaitkan dengan fleksibilitas protein, derajat kebebasan ligan dan protein, efek entalpi dan entropi [21, 22].



Gambar 2. Interaksi ko-kristal PIM unduhan dari wwPDB (A) dan hasil penambatan ulang, dan (B) terhadap residu 2D0T secara 3D (kiri) dan 2D (kanan).

Tabel 2. Nilai Afinitas Ikatan Ligan 1 dan L-1MT

\begin{tabular}{|c|c|}
\hline Ligan & (Pose) Afinitas lkatan (kkal/mol) \\
\hline $1 \mathrm{a}$ & (1) $-0,3 ;(2)-0,1 ;(3) 1,9$ \\
\hline $1 \mathrm{~b}$ & (1) 0,$3 ;$; 2 (2),4; 0,$9 ;(4) 2,3$ \\
\hline 1c & (1) 1,$0 ;(2) 1,6 ;(3) 3,9$ \\
\hline L-1MTa & (1) $-2,2 ;(2)-1,9 ;(3)-0,8 ;(4)-0,8 ;(5)-0,7 ;(6) \quad 0,0$ \\
\hline L-1MTb & (1) -1,0; (2) -0,9; (3) -0,6; (4) -0,6; (5) -0,3; (6) 0,5; (7) 0,6; (8) 1,4; (9) 1,8 \\
\hline L-1MTc & (1) -1,2; (2) -1,0; (3) -0,8; (4) -0,8; (5) -0,4; (6) 0,5; (7) 1,$4 ;$ (8) 1,7 \\
\hline
\end{tabular}

\subsection{Visualisasi Hasil Penambatan Molekular}

Afinitas ikatan merupakan nilai kekuatan interaksi antara protein dan ligan yang semakin besar apabila nilainya semakin rendah. Interaksi ini terdiri atas ikatan hidrogen, interaksi elektrostatik, interaksi van der Waals, dan interaksi hidrofobik. Akan tetapi, metode simulasi komputasi hanya mampu menduga interaksi berdasarkan jarak antar atom dan sifat atomik senyawa dengan protein. Ikatan hidrogen dilaporkan dapat dikategorikan berdasarkan jarak donor-aseptor 


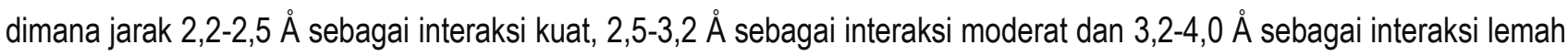
[18].
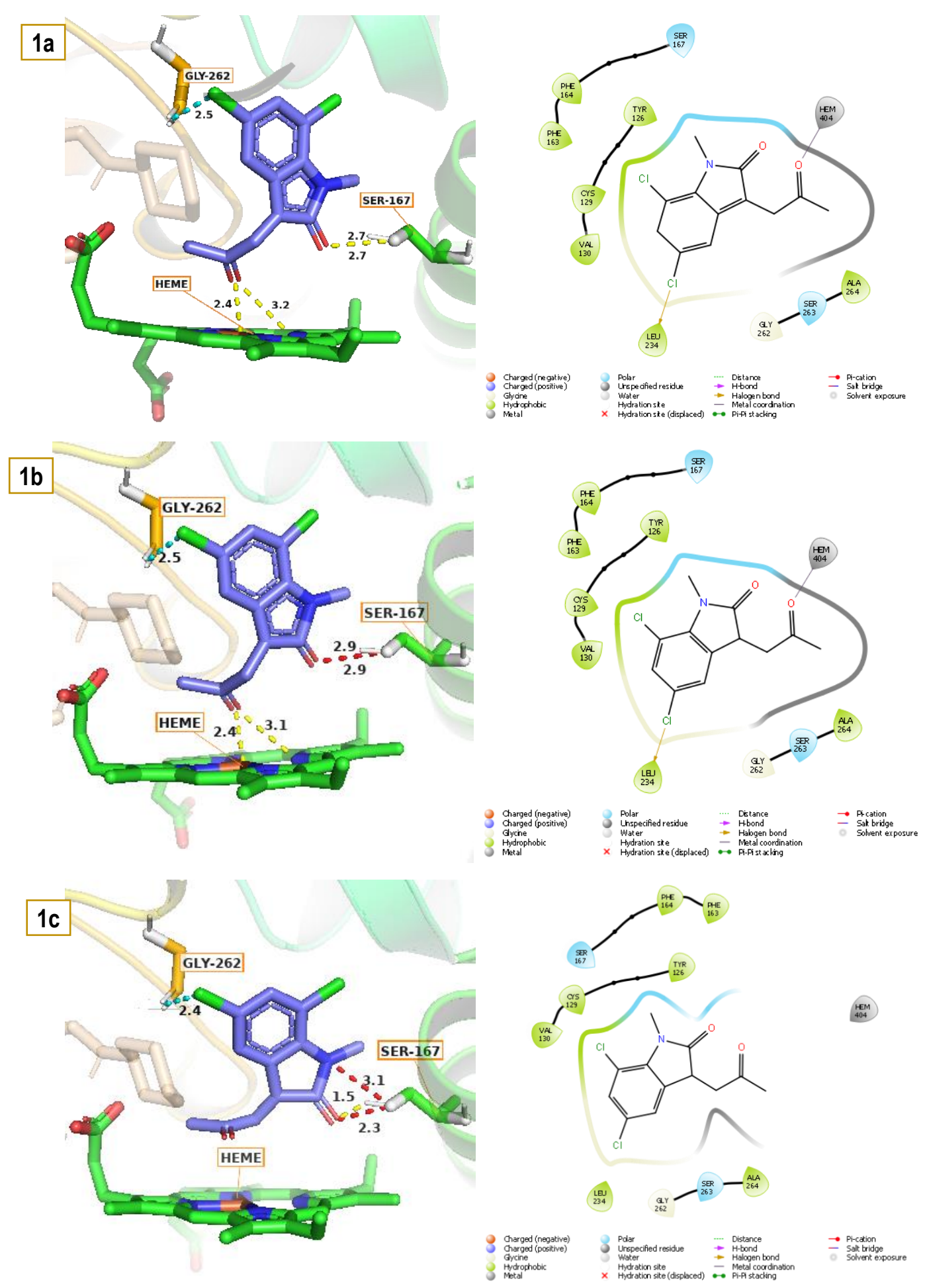

Gambar 3. Visualisasi interaksi 3D (kiri) dan 2D (kanan) senyawa 1 dengan 2D0T

Visualisasi hasil penambatan senyawa 1 pada pose terbaik (pose 1) menunjukkan adanya interaksi melalui donor ikatan hidrogen (hydrogen bonding donor, HBD), akseptor ikatan hidrogen (hydrogen bonding acceptor, HBA), dan ikatan polar (Gambar 3). Senyawa 1a berinteraksi melalui atom Cl pada cincin benzena dengan residu GLY262 (HBD; $2,5 \AA$ ), gugus karbonil oksindola dengan residu SER167 (HBA dan ikatan polar; 2,7 ̊), dan ikatan polar antara atom oksigen dengan Fe-Heme $(2,4 \AA)$ dan $\mathrm{N}$-Heme $(3,2 \AA)$. Interaksi lainnya berupa ikatan koordinasi antara ligan Heme dan ikatan halogen dengan residu LEU234. Pola interaksi yang sama ditunjukkan oleh senyawa $\mathbf{1 b}$ dan $\mathbf{1 c}$ dengan jarak yang lebih panjang. Senyawa 1c hanya menunjukkan satu ikatan polar dan tidak memiliki interaksi melalui ikatan koordinasi, ikatan 
polar, dan ikatan halogen. Perbedaan interaksi yang terjadi dan jarak ikatan yang bervariasi membuktikan bahwa minimisasi energi berpengaruh terhadap hasil penambatan molekular.
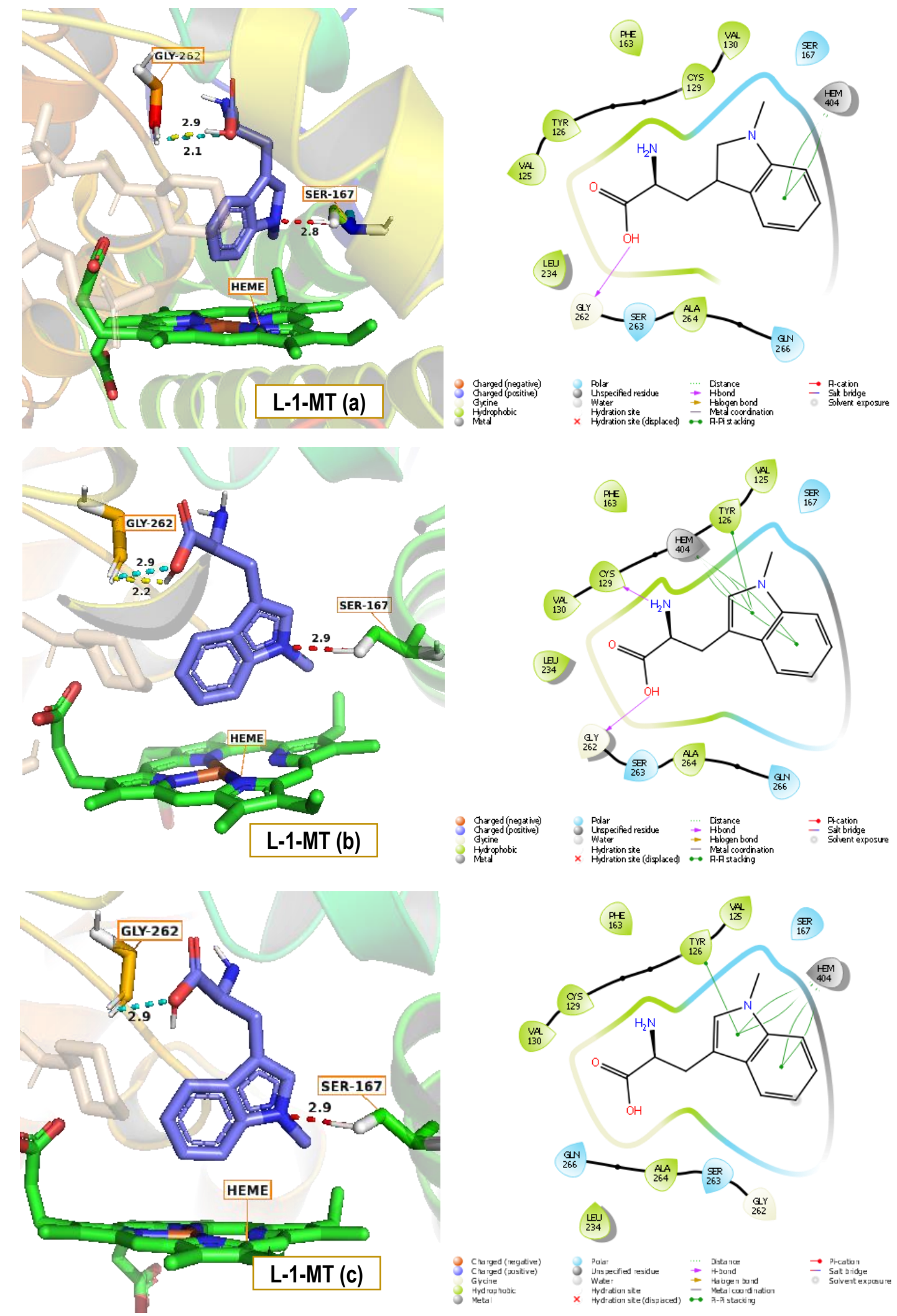

Gambar 4. Visualisasi interaksi 3D (kiri) dan 2D (kanan) senyawa L-1MT dengan 2D0T

Hasil penambatan L-1MT selanjutnya divisualisasi untuk memastikan perbedaan minimisasi energi terhadap interaksi yang terjadi (Gambar 4). Secara umum, L-1-MT tidak menunjukkan interaksi dengan Heme melalui ikatan polar. Senyawa 
L-1-MTa berinteraksi dengan residu GLY262 melalui HBD (2,9 Å) dan ikatan polar $(2,1 \AA$ A $)$. Senyawa ini juga berinteraksi dengan residu SER167 melalui HBA dan menunjukkan interaksi phi-phi stacking antara cincin benzen dengan Heme. Senyawa L-1-MTb menunjukkan pola interaksi yang sama dengan L-1MTa dengan tambahan ikatan hidrogen antara gugus amina dengan residu CYS129. Senyawa L-1-MT(c) tidak memiliki interaksi ikatan polar tetapi mempunyai tiga interaksi phiphi stacking (cincin benzen dengan Heme, cincin pirola dengan Heme, cincin pirola dengan TYR126). Interaksi lainnya yang terbentuk adalah HBA atom nitrogen pada gugus amida dengan residu SER167 dan interaksi HBD gugus karbonil dengan residu GLY262.

Uraian di atas memberikan gambaran bahwa optimasi melalui minimisasi energi berpengaruh terhadap penambatan molekular. Minimisasi energi memberikan dampak signifikan terhadap nilai energi minimisasi, afinitas ikatan, dan visualisasi interaksi. Minimisasi energi senyawa 1 menggunakan MarvinSketch menghasilkan konformasi struktur dengan afinitas ikatan yang lebih rendah dari pada yang lain. Hasil ini didukung oleh minimisasi energi dan penambatan molekular L-1MT terhadap makromolekul 2D0T yang juga menunjukkan profil yang sama. Senyawa 1 dan L-1MT menunjukkan interaksi yang beragam terhadap residu makromolekul 2DOT.

\section{Kesimpulan}

Penambatan molekular silang senyawa 1 dan L-1MT terhadap makromolekul 2D0T dengan perbedaan optimasi minimisasi energi telah berhasil dilakukan. Minimisasi energi menggunakan MarvinSketch dan Open Babel PyRx, dan tanpa minimisasi energi menghasilkan nilai energi minimisasi, binding affinity, dan interaksi yang berbeda. Penambatan molekular dengan minimisasi energi menggunakan MarvinSketch memberikan hasil afinitas ikatan paling rendah dan visualisasi interaksi ikatan paling baik dari lainnya.

\section{Ucapan Terima Kasih}

Penulis berterima kasih kepada ITS melalui Penelitian Kerjasama Antar Perguruan Tinggi (Pakerti) (958/PKS/ITS/2020).

\section{Daftar Pustaka}

[1] C. Bilir \& C. Sarisozen, "Indoleamine 2,3-dioxygenase (IDO): Only An Enzyme or A Checkpoint Controller?," Journal of Oncological Sciences, vol. 3, pp. 52-56, 2017.

[2] M. Platten, E. A. A. Nollen, U. F. Rohrig, F. Fallarino, \& C. A. Opitz, "Trypthopan Metabolism as a Common Therapeutic Target in Cancer, Neurodegeneration and Beyond," Nature Reviews Drug Discovery, vol. 18, no. 5, pp. 379-401, 2019.

[3] C. Zhou, F. Lai, L. Sheng, X. Chen, Y. Li, \& Z. Feng, "Design, Synthesis and Biological Evaluation of Phenyl Urea Derivatives as ID01 Inhibitors," Molecules, vol. 25, no. 1447, 2020.

[4] S. R. Rudrangi, V. K. Bontha, V. R. Manda, \& S. Bethi, "Oxindoles and Their Pharmaceutical Significance - An Overview," Asian Journal of Research Chemistry, vol. 4, no. 3, pp. 335-338, 2011.

[5] G. Pauntouris, J. Loudon-Griffiths, \& C. G. Mowat, "Insight Into The Mechanism of Inhibition of Tryptophan 2,3Dioxygenase by Isatin Derivatives," Journal of Enzyme Inhibition and Medicinal Chemistry, vol. 31, pp. 70-78, 2016.

[6] S. Paul, A. Roy, S. J. Deka, S. Panda, G. N. Srivastava, V. Trivedi, \& D. Manna, "Synthesis and Evaluation of Oxindoles as Promising Inhibitors of the Immunosuppressive Enzyme Indoleamine 2,3-dioxygenase 1," Medicinal Chemistry Communications, vol. 8, no. 8, pp. 1640-1654, 2017.

[7] T. Nogrady, \& D. F. Weaver, Medicinal Chemistry: A Molecular and Biochemical Approach, $3{ }^{\text {rd }}$ Edition. New York: Oxford University Press, 2005.

[8] A. Jász, A. Rák, \& G. Cserey, "Energy Calculation of MMFF94 Force Field on GPU (Special Session on Array Computing Systems and Applications)." dalam European Conference on Circuit Theory and Design (ECCTD), 2017.

[9] M. Ganesan, K. K. Raja, S. Murugesan, B. K. Kumar, G. Rajagopal, \& S. Thirunavukkarasu, "Synthesis, Biological Evaluation, Molecular Docking, Molecular Dynamics and DFT Studies of Quinoline-fluoroproline Amide Hybrids," Journal of Molecular Structure, vol. 1217, no. 128360, 2020.

[10] C. M. Nisha, A. Kumar, P. Nair, N. Gupta, C. Silakari, T. Tripathi, \& A. Kumar, "Molecular Docking and In Silico ADMET Study Reveals Acylguanidine 7a as a Potential Inhibitor of $\beta$-Secretase,". Advances in Bioinformatics, vol. 2016, 2016.

[11] C. Kiank, J.-P. Zeden, S. Drude, G. Domanska, G. Fusch, W. Otten, \& C. Schuett, "Psychological Stress-Induced, ID01-Dependent Tryptophan Catabolism: Implications on Immunosuppression in Mice and Humans," PLoS ONE, vol. 5, no. 7, 2010.

[12] T. ten Brink \& T. Exner, "pKa Based Protonation States and Microspecies for Protein- Ligand Docking," Journal of Computer-Aided Molecular Design, vol. 24, pp. 935-942, 2010.

[13] W. J. Allen, \& R. C. Rizzo, "Implementation of the Hungarian Algorithm to Account for Ligand Symmetry and Similarity in Structure-Based Design," Journal of Chemical Information and Modeling, vol. 54, pp. 518-529, 2014. 
[14] T. H. Cormen, C. E. Leiserson, R. L. Rivest, \& C. Stein, Introduction to Algorithms, 3rd Ed. Massachussetts:The MIT Press, 2009.

[15] P. Tiikkainen, "Study of Ligand-Based Virtual Screening Tools in Computer-Aided Drug Design," PhD Dissertation, University of Turku, Finland, 2010.

[16] R. Barret, M. Berry, T. F. Chan, J. Demmel, J. Donato, J. Dongarra, V. Eijkhout, R. Pozo, C. Romine, \& H. van der Vorst, "Templates for The Solution of Linear Systems: Building Blocks for Iterative Methods," Society for Industrial and Applied Mathematics (SIAM), 1994.

[17] H. Sugimoto, S.-I. Oda, T. Otsuki, T. Hino, T. Yoshida, \& Y. Shiro, "Crystal Structure of Human Indoleamine 2,3Dioxygenase: Catalytic Mechanism of $\mathrm{O}_{2}$ Incorporation by A Heme-containing Dioxygenase," PNAS, vol. 103, no. 8 , pp. 2611-2616, 2006.

[18] G. A. Jeffrey, An Introduction to Hydrogen Bonding. New York: Oxford University Press, 1997.

[19] E. W. Bell \& Y. Zhang, "DockRMSD: An Open-Source Tool for Atom Mapping and RMSD Calculation of Symmetric Molecules Through Graph Isomorphism," Journal of Cheminformatics, vol. 11, no. 40, 2019.

[20] G. Even, J. S. Naor, S. Rao, \& B. Schieber, "Divide-and-Conquer Approximation Algorithms via Spreading Metrics," Journal of the ACM, vol. 47, no. 4, pp. 585-616, 2000.

[21] C. S. Rapp, C. Kalyanaraman, A. Schiffmiller, E. L. Schoenbrun, \& M. P. Jacobson, "A Molecular Mechanics Approach to Modeling Protein-Ligand Interactions: Relative Binding Affinities in Congeneric Series," Journal of Chemical Information and Modeling, vol. 51, no. 9, pp. 2082-2089, 2011.

[22] G. Klebe \& H.-J. Bohm, "Energetic and Entropic Factors Determining Binding Affinity in Protein-Ligand Complexes," Journal of Receptors and Signal Transduction, vol. 17, no. 1-3, pp. 459-473, 1997. 